\title{
PANDA Questionnaire in the Greek population: preliminary data
}

\author{
Ilia Theotoka*, Vasilis Vagenas, Evangelos Kouremenos, Elissavet Kapaki, Maria Maltezou, Ioannis Liappas \\ From $1^{\text {st }}$ International Congress on Neurobiology and Clinical Psychopharmacology and European \\ Psychiatric Association Conference on Treatment Guidance \\ Thessaloniki, Greece. 19-22 November 2009
}

\section{Background}

The aim of this work is to validate in greek population the PANDA Questionnaire for the assessment of mild cognitive deficits and dementia in patients with Parkinson's disease.

\section{Materials and methods}

The study included two groups. The first consisted of 20 patients with Parkinson's disease, who were outpatients in the Movement Disorder Clinic and the Memory Clinic of the Neurological Clinic of two public health general hospitals and a university hospital. The second consisted of 20 healthy controls. The two groups were matched for age and education. Patients with Parkinson's disease were evaluated by an experienced clinical neuropsychologist with Mini Mental State Examination, Clock Test, Instrumental Activities of Daily Living. Healthy controls were evaluated only with Mini Mental State Examination, in order to ensure normal cognitive status. In the two groups, PANDA Questionnaire was also administered.

\section{Results}

PD patients performed statistically significantly worse than controls in all PANDA subtests, except the first subtest of immediate recall, where the two groups did not differ. PANDA is very well correlated with all neuropsychological tests. Healthy controls were intact cognitively with all instruments.

\section{Conclusions}

Greek version of PANDA can be an effective tool. PANDA has a good correlation with all tests used in

Athens University Medical School, Department of Psychiatry and Neurology, Eginition Hospital, Department of Neurology 1st IKA Hospital of Athens, Department of Neurology, 251 GNA of Athens, Greece this study and differentiates well PD patients from controls. Small sample size is a limitation of the study. In order to complete the validation study, we need a bigger sample.

Published: 22 April 2010

doi:10.1186/1744-859X-9-S1-S210

Cite this article as: Theotoka et al:: PANDA Questionnaire in the Greek population: preliminary data. Annals of General Psychiatry 2010 9(Suppl 1): S210.
Submit your next manuscript to BioMed Central and take full advantage of:

- Convenient online submission

- Thorough peer review

- No space constraints or color figure charges

- Immediate publication on acceptance

- Inclusion in PubMed, CAS, Scopus and Google Scholar

- Research which is freely available for redistribution

Submit your manuscript at www.biomedcentral.com/submit
C Biomed Central 